\title{
THE THORNY ROSE: THE AVOIDANCE OF PASSION IN MODERN INDONESIAN LITERATURE ${ }^{1}$
}

\author{
Harry Aveling
}

One of the important shortcomings of modern Indonesian literature is the failure of its authors, on the whole young, well-educated men of the upper and more modernized strata of society, to deal in a convincing manner with the topic of adult heterosexual passion. This problem includes, and partly arises from, an inadequacy in portraying realistic female characters which verges, at times, on something which might be considered sadism.

What is involved here is not merely an inability to come to terms with Western concepts of romantic love, as explicated, for example, by the late $\mathrm{C}$. $\mathrm{S}$. Lewis in his book The Allegory of Love. ${ }^{2}$ The failure to depict adult heterosexual passion on the part of modern Indonesian authors also stands in strange contrast to the frankness and gusto with which the writers of the various branches of traditional Indonesian and Malay literature dealt with this topic. Indeed it stands in almost as great a contrast with the practice of Peninsular Malay literature today.

In Javanese literature, as Pigeaud notes in his history, The Literature of Java, "Poems and tales describing erotic situations are very much in evidence. . . descriptions of this kind are to be found in almost every important mythic, epic, historical and romantic Javanese text." ${ }^{3}$ In Sundanese literature, there is not only the open violence of Sang Kuriang's incestuous desires towards his mother (who conceived him through intercourse with a dog), and a further wide range of openly sexual, indeed often heavily Oedipal stories, but also the crude directness of the trickster Si-Kabajan tales, which so embarrassed one commentator, Dr. L. M. Coster-Wijsman, that she felt obliged to leave some sections untranslated in her text. ${ }^{4}$

The recited penglipor lara tales of Sumatra and Malaya, "folk-romances" as Sir Richard Winstedt referred to them, "are

1. This paper owes much to the stimulation of Leslie A. Fiedler's Love and Death in the American Novel (New York: Criterion, 1960).

2. (London: Oxford University, 1936).

3. (The Hague: Nijhoff, 1967), I, P. 274.

4. Uilenspiegel-verhalen in Indonesia (Santpoort: Mees, 1929).

5. History of Malay Literature. Monographs on Malay subjects, No. 5. (Singapore: Royal Asiatic Society, 1958), p. 26. 
obviously more than just adventure stories; ${ }^{6}$ their main theme is the physical attraction which exists between the hero and the heroine, and the tribulations which that attraction suffers before its consummation. In these tales, which the female audience heard separated from their men-folk, ${ }^{7}$ to see, to desire and to couple are all part of one continuous process. The adventure arises from the desire of the villain for the heroine, both against her will and that of the hero. Towards the man she loves, the heroine of the penglipor lara tale is often a strong, active and sexually demanding character--witness the Tuan Puteri Dayang Seri Jawa in the Hikayat Awang Sulong Merah Muda, ${ }^{8}$ or the Tuan Puteri Bongsu Jagat Jaga Dibulan, and Intan Baiduri, in the Cherita Selampit. ${ }^{9}$

In modern Indonesian literature, we miss those themes so common in the classical indigenous, and other, modem, literatures: the themes of flirtation, seduction, adultery, rape, and the full bodily, intellectual and emotional commitment of lovers (married or not) to each other as equal human beings. There is, on the contrary, a prudery about the body and its functions, and an elaborate pretence that marriage--and even parenthood--is sustained without reference to sex. The role of the heroine is usually taken by the "pure young maiden," who has grown up in sheltered seclusion under the indulgent care of her only surviving parent, her father. She is often a dull unthinking figure (at least, until it is too late), calmly submissive to the vicissitudes which inevitably befall her, and doomed to a youthful death which is at once sentimentally moving and grotesquely laughable. ${ }^{10}$ The hero is often no less dull,

6. Compare Aning Retnaningsih, Roman dalam Masa Pertumbuhan Kesusasteraan Indonesia Modern (Djakarta, 1965): "Semua hikajat selalu mempunjai tema sama, jaitu pada pokok tjeritera tentang pahlawan-pahlawan jang gagah berani jang sanggup merpertahankan kebenaran-kebenaran." ["Every folkromance always has the same theme; it is basically the story of a brave man prepared to defend truth."], p. 17 .

7. W. E. Maxwell, "Penglipor Lara," Journal of the Straits Branch, Royal Asiatic Society, part l (1886), p. 86: ". - TThe penglipor lara] has very likely been placed [for his recitation] near a doorway leading to the women's apartment and the laughter and applause of the audience without is echoed from behind the curtains, where the women of the household sit listening eagerly."

8. (Singapore: Malay Publishing House, 1960).

9. (Kuala Lumpur: Dewan Bahasa dan Pustaka, 1959).

10. See also Armijn Pané, "Mengapa Pengarang Modern Suka Mematikan?" Pudjangga Baru, 8, No. 9 (1941), pp. 225-231. 
although there is more variety possible in his dullness: he may be a man of action who knows no emotion, an intellectual without feeling, or a tortured introvert knowing nothing of the reality of the outside world. Like the typical heroine, he may suffer from having been sheltered from life's harshness by a sole surviving parent, in his case, the mother.

The short story "Ia Masih Ketjil" by W. S. Rendra"1 is almost a paradigm of this type of literature. In this story, the younger brother wants to become an army general when he grows up, so that he can kill those men who wish to defile his sister, who is meanwhile necking with her boyfriend in the next room. In the eyes of the commentator, to make love is to commit a sin (berdosa). It is the violence of the corrupt and unsympathetic male in the conquest of the unwilling and ever pure female. 12

Passion is avoided in modern Indonesian literature, particularly in modern Indonesian prose, mainly by three kinds of devices. ${ }_{3}$ All of them involve a refusal to treat the woman as an equal of the man. Furthermore, all of them build on a sentimentalization of roles, such that other types of malefemale relationships are substituted for those of lovers.

11. In Ia Sudah Bertualang (Djakarta: Nusantara, 1963).

12. It could be argued that this is just a child's view of his sister's activities. This may well be so, and still not affect the paradigm. In any case, I am not convinced that the child's parent's view of the situation--"They are grownup people who want to become a mummy and a daddy,"--is very much better.

13. These avoidance devices cannot, in the first place, at any rate, be assumed to derive from any social reality which is being mirrored in the literature. Nor can I say here why such devices are so frequently used. Although both questions are obviously interesting in themselves, to answer them one would need to range over vast areas of comparative literature, sociology, ethics, education, and developmental psychology.

Compare Vincent Buckley's comment that, ". . . keeping the eye on the object is precisely what literary studies need. . ." at the moment, made in Poetry and Morality: Studies on the Criticism of Matthew Arnold, T.S. Eliot and F. R. Leavis (London: Chatto and Windus, 1959), p. 16 . The Australian Associated Press correspondent to the Melbourne Herald (June 4, 1968) argues that the factors which combine to given Indonesia its "prim facade" are "isolation, censorship, Moslem austerity, lingering Dutch influence, and inbred moral restraint."

I would welcome any comments on this article which sociologists, psychologists or literary critics might like to make. 
The first two devices involve the placing of the partners in a pseudo-kinship relationship--brother to sister or mother to son--in which sex is commonly assumed to be absent, or a factor of no importance.

The thind device, which is a response to a situation in which the sexuality of the female is felt to be an overwhelming challenge to the superiority of the male, involves moving the female out of the circle of people towards whom the male might reasonably be expected to have moral and social responsibilities. She may be simply someone from a lower class than the male, or she may actually be degraded into a prostitute or seductress. (As we shall see, even this last relationship can be sentimentalized.)

By assuming the roles of brother and sister, or more strictly, elder brother and younger sister, the characters of the novel or short-story are moved back into the world of childhood where sex, though perhaps latent, is quite irrelevant. In this child-like world, it is the task of the older brother to protect his little sister and to care for her needs. She, in turn, is dependent on him and admires him for his superior strength and courage; she knows, too, that he will never hurt her in any way, certainly not sexually. It must be stressed that the couple do not simply call each other abang (elder brother) and adik (young sister) as polite Indonesian and the various Indonesian regional languages usually require lovers to do. They have been bred under conditions approximating that of brother and sister, and in daily life behave towards one another in this way.

The world of Miriamin and Aminuddin, the hero and heroine of Merari Siregar's Azab dan Sengsara, and of Sitti Nurbaja and Samsulbahri, who play the same parts in Marah Rusli's Sitti Nurbaja, is of this type. In both cases, the childish world is destroyed irrevocably when a mature adult male is thrust upon the naive young girl by the insensitive community of grown-ups. Kasibun, Miriamin's husband in the first book, is so depraved that he actually has a venereal disease. Under Moslem law, this is one of the grounds on which a woman may successfulily petition for a divorce, 14 although Miriamin apparently has no knowledge of this possibility.

Datuk Meringgih, the melodramatic villain of the second novel, has two evil characteristics which are constantly

14. "Fasah (or faskh, or pasah) is the dissolution of a Muslim marriage by judicial decree, and, according to the Shafi'i school, a spouse may apply for such a decree on the grounds of impotence, insanity, or a serious and repellent disease, such as leprosy or venereal disease." Judith Djamour, The Muslim Matrimonial Court in Singapore (London: Athlone, 1966), p. 77 . 
emphasized. The first is that he is an unscrupulous and miserly merchant intruding into a formerly closed circle of aristocrats; the other is that he has had so many wives that no one can keep count of them any longer. According to James Peacock, in East Java "aggression in trade seems (in popular belief) to correlate with the legendary length of a trader's phallus." 15 If this is also true of the Minangkabau area from where Rusli originated [Idrus, a leader of the literary Angkatan '45 (Generation of 145) has assured me that among the Minangkabau, traders are felt to have reserves of sexual energy not available to other men, who are more involved in their work], ${ }^{16}$ then these two traits of Datuk Meringgih's personality are different sides of the same coin. It is this virility figure who tears Sitti Nurbaja away from her schoolfriends, and who forcibly prevents her from ever reuniting with them except in death. In the last scene of the book, set in a graveyard, they and Samsulbahri, who sleeps beside her in perpetual innocence, are still virginal. (Despite the critics, and even Marah Rusli's statements in his later novel Anak dan Kemanakan, ${ }^{17}$ the main plot of Sitti Nurbaja has absolutely nothing to do with adat or its break-down. Sit.ti Nurbaja's marriage to Datuk Meringgih is forced on her by her father's circumstances and not by any customary arrangements; and it is her choice alone which finally settles the marriage.)

Maria and Jusuf, too, in Sutan Takdir Alisjahbana's Lajar Terkembang are no more than schoolchildren, living their dream of love in a sexless world of breath-taking unreality. After their first adolescent kiss, they are described as walking by a swiftly flowing stream, "two children, extremely close playmates, one larger and swifter than the other."18 Before the end of the novel, Alisjahbana kills Maria off with tuberculosis. She is too light-hearted, too innocent, too willingly defenseless, to suffer the responsibilities of marriage and the harshness of motherhood. If, in the first half of the book, Alisjahbana does not treat Tuti, Maria's older and more intellectual sister, very sympathetically, she is nevertheless always shown to be more capable of looking after herself with men, as her broken engagements reveal. In this, as well as in all other facets of their

15. "Ritual, Entertainment and Modernization: A Javanese Case," Comparative Studies in Society and History (April 1968), p. 332. Peacock's book The Rites of Modernization: Symbolic and Social Aspects of Indonesian Proletarian Drama (Chicago: University Press, 1968), which I received only after the completion of this article, gives ample scope for contrast with the practices of modern Indonesian literature.

16. He was less sure if Indonesian traders were as "king-size" as Arab traders were reported to be.

17. (Melaka: Abbas Bandong, 1966), PP. 173-174.

18. (Kuala Lumpur: Bi-Karya, 1963), p. 68. 
characters, the two sisters are presented in the deliberate fair-dark, innocent-knowing, contrast of folklore. This contrast might be pursued with other such pairs of women in Indonesian literature: Corrie and Rapiah, the European and Indonesian wives of the Dutchified Hanafi in Salah Asuhan; Sumartini and Jah, wife and mistress of Dr. Sukartono in Belenggu; and the wife and mistress of Sitor Situmorang in such poems as "Chathedrale de Chartres," in Surat Kertas Hidjau.

The second device for avoiding passion is to recast the relationship of lovers into one between mother and son. In this situation, the woman's subordination in the brother and sister couple is reversed; now it is the man who becomes the passive recipient of the love and care which the woman willingly bestows upon him. He gives nothing, he receives everything; she is honored simply in the measure of her giving.

In Armijn Pane's Belenggu, most of the mutually-destructive friction between the sensitive Dr. Sukartono and his Westernized socialite wife arises because she absolutely refuses to mother him. He argues: "A woman's 'right' [hak] is to look after her child and husband [anak suaminja] and to run the house. . . Although they like to welcome their husbands when they come home from work, they forget to invite them to sit down, they let them take off their own shoes. Don't these modern women know that if they kneel before their husbands to undo their shoes, they are showing their love, their faithfulness? What else ought a woman do, other than give all her attention to her husband?" 19 What else indeed, when any interest outside the home has the apparent effect of turning a woman into an unlovely and mannish person like sumartini and Tuti and Rukajah, the satirized fighter for equal rights for women in Sontani's Bunga Rumah Makan? Jah, Sukartono's mistress, knows how to look after him: "Care for him"--she tells sumartini--"do what he wants, attend to those little things that he likes which are so important." 20 For, as she says, "all men are the same," all are little boys who need continually to be spoiled, and mother must slave for her little man if he will not look after himself.

Utuy Tatang Sontani, in one of his last plays, Tak Pernah Mendjadi Tua, actually has the wife, Njonja Isak, say to her husband in an argument: "Yes, you are the child I spoiled most, sir, the child who came to me when [our son] Dudung was born, came asking to be cared for, to be looked after, and to be guarded day and night, to have your food seen to, your clothes looked after, your health safe-guarded. And I did it all lovingly, sweet child, I did it all with my woman's full

19. (Djakarta: Pustaka Rakjat, 1961), P. I5.

20. Pané, Belenggu, p. 117. 
awareness, as a mother who knew that you needed all of that." 21

Corrie, Hanafi's "Dutch"--actually French-Indonesian-wife, in Abdul Muis' Salah Asuhan, refuses to spoil him as his mother did, or to behave towards others in the same discreet style his mother favored. Idrus, in a critique of this book, blames Hanafi's mother for everything, arguing that Hanafi was not the victim of a forced marriage, nor of his denying his own Indonesian tradition, but of "the tacit acceptance by his mother of Western civilization. In herself, this attitude creates snobbishness, and in her son, obsession, which in turn creates confusion throughout the community." 22 In fact, Hanafi's two most grievous offenses in the book, other than his extreme aping of Dutch manners, which his mother wished upon him, seem to be his ill-treatment of the mother of his son, and his ingratitude towards his own mother.

Hasan, the emotional, religious hero of Achdiat K. Mihardja's Atheis, has the same trouble with his wife, Kartini. Kartini is named after Raden Adjeng Kartini, famous for her struggle for women's equality, who has come, ironically enough, to be seen by Indonesians as the ideal mother-figure, with many children playing around her feet. Despite the marriage, and Kartini's previous living with Hasan's school-friend Rusli, Atheis can only be described as a coy novel. Of the fifteen parts of the book, one (Section XI) deals with the marriage, and it takes less than half a page. ${ }^{2}{ }^{3}$ The affair between Kartini and Rusli, perhaps because we see it though Hasan's eyes, is never explicitly described to be such. The scene in which Anwar (modelled on Chairil Anwar) attempts to seduce, then rape, Kartini, is Iudicrous.

Finally, one should note how Taufiq Ismail, literary spokesman of the so-called "Generation of $166^{\prime 24}$ rages at those who have ruined the country, openly committed adultery and abused the honor of women, our mothers' kin ["kaum dari ibu kita"], ${ }^{25}$ or his

21. Quoted from Teruna Bhakti, June 29, 1963, p. 23. The play was published in five parts in Teruna Bhakti, between June 8 and July 6, 1963. My text is from a typed copy of the play held at the Lembaga Bahasa dan Kesusasteraan, Djakarta. This play is in startling contrast to Sontani's other two plays written as an executive member of Lekra, Si-Kampeng and Si-Sapar.

22. "East-west Conflict and Indonesian Novels," Quadrant (Sydney) (November-December 1966), p. 41.

23. (Melaka: Abbas Bandong, 1966), P. 162.

24. H. B. Jassin, "Angkatan 66, Bangkitnja Satu Generasi," Horison, 1, No. 2, (1966).

25. "Kemis Pagi," Benteng (Djakarta: n.p., 1966), p. 21. 
depiction of the rambutan-vendor who tells his wife how the students cheered him when he supported them. He behaves like a child telling his mother of some great treat--"They cheered me! Really cheered me, bu. . . ."26

"But surely there are some women in Indonesian literature who respond eagerly and joyously to love-making?" the reader may ask: not expecting perhaps an Emma Bovary, an Anna Karenina or a Hester Prynne, ${ }^{27}$ but, nevertheless, stirred by the name of Jah.

There are, and, like Jah, they are mostly women of no account in society ( $\mathrm{Jah}$ is a prostitute). As "fully mature" 28 a novel as Belenggu undoubtedly is, it is still too radical for Sukartono to have an adulterous liaison with the wife of a friend, or patient of his own social status and circumstances. It is only with a woman already depraved, in this case an experienced prostitute, that this is possible. It is always a previous act of lust, the bestiality of some other male, momentarily consented to or not, which first set the prostitute on her downward path. This is what happened to Jah, to Midah in Pramoedya Toer's, Midah--Simanis Bergigi Emas, and what happens in W. S. Rendra's tales of "unfortunate people." 29 (Midah, unlike the others, becomes quite rich, and even has a successful career in films as the wages of sin, but then actors and actresses have always been seen as morally doubtful people.) The guilt of the male, as a male, is both assuaged--"she is only a prostitute"--and doubled--"I am consorting with prostitutes. It is in this way she got her start, poor thing."

But usually there are ways of minimizing male guilt for enjoying intercourse with her. In many cases economic difficulties have left the sordid trade of prostitution as the only way a girl could earn a living: "The bosses, would only open the doors of opportunity / if we would open our thighs," as Rendra's poem "Pelatjur Djakarta, Bersatulah!" 30 puts it. Thus Jah is actually an old school-friend of Sukartono's, fallen on hard times. Or is she? He is never quite sure. The prostitute may also be described as a woman with a heart of

26. "Seorang Tukang Rambutan kepada Isterinja," Tirani (Djakarta: Birpen Kami, 1966), p. 24.

27. Hester Prynne is of course the main female character in Nathaniel Hawthorne's The Scarlet Letter.

28. A. H. Johns, "Genesis of a Modern Literature," in Ruth McVey (ed.), Indonesia (New Haven: H.R.A.F., 1963), p. 418.

29. Ballada Orang-Orang Tertjinta (Djakarta: Pembangunan, 1957).

30. Horison, 3, No. I (1968). I have translated this poem in Tenggara (Kuala Lumpur, University of Malaya) 2, No. 2 (1968). 
gold, who understands and forgives more than other women do, as in Sontani's Selamat Djalan Anak Kufur! or closer to God than the hypocritical churchwomen who sit in judgement on her, as in Rendra's "Kami Pergi Malam-Malam." ${ }^{3}$ In a wild inversion of the tradition of erotic mysticism to which Amir Hamzah belonged, one of Rendra's poems even has a prostitute enter heaven through intercourse with the most beautiful man she has ever known, Christ himself. 32

One last final way to assuage male guilt is for the male to step outside the boundaries of his own status group. Thus if the woman is not actually a prostitute, sh- is still "degraded" by being outside the world in which he "really" lives. The relationship is not one of equal commitment, and she, the woman, is still "trash." In modern Indonesian literature, students do not sleep with other students, or bureaucratcapitalists with the wives of other bureaucrat-capitalists, but both may couple with the wives of lesser men, poorer men, or women of no account in society.

Male vanity is such that only rarely is the woman ignorant of her lover's higher social status. Occasionally, the male may pretend to be of her station. He may appear, for example, as a sailor, as we seem to find in the verse of Chairil Anwar, who otherwise appears incapable of giving himself to a "good" woman, for fear of hurting himself. ${ }^{3}$

More commonly, the disparity is quite obvious. There are the slum-dwelling "aunt" in Mochtar Lubis' Tanah Gersang, who sleeps with the hoodlum rich boy; the kampung woman, Marlina, with her newly and, of course, dishonestly, rich orang kaja baru lover in Sontani's Dilangit ada Bintang; or, again in Lubis' novels, the "gold-digger" stepmother, of no definite background, who has relations with her new "son" while his father's back is turned, in Sendja Di-Djakarta and Djalan Tak Ada Udjung. In the work of Sontani, particularly in the plays of his middle period (1953-1957), Manusia Iseng, Sa'at Jang Genting and, perhaps, Dimuka Katja, we find the sister of the man's wife, who is young enough to be his daughter, tempting him into sexual relations.

Finally, there is the complete foreigner: Mrs. Frits, for example, in Seri Siregar's short-story "Dosa atas Manusia," who first seduces a young Indonesian, then is admonished and

31. Empat Kumpulan Sadjak (Djakarta: Pembangunan, 1961), pp. 113-115.

32. "Njanjian Angsa," Horison, 3, No. 1; and also Tenggara, 2, No. 2 .

33. See, for example: "Tak Sepadan," "Sia-Sia" and "Penerimaan" in Kerikil Tadjam (Djakarta: Pustaka Rakjat, 1949). 
finally reassured by him: "I am still extremely young, Mrs. Frits. You should have strengthened my power of resistance. You knew my weaknesses and how to oppress those who are weak. You made use of that knowledge excellently. . . . [But] you still have time to repent. The door is still wide open. I am prepared to lead you, and to walk in front of you as a guide." 34 For one so easily, so willingly seduced, the hypocrisy is incredible, the innocence unbelievable. ${ }^{35}$

So far as I know, only two couples in modern Indonesian literature think that they might exist as equals on all levels, although emotion is not mentioned explicitly in either case. sukartono and Sumartini, whose marriage is discussed above, are one couple. Their marriage, in its emotional and physical sterility, is a failure.

The other marriage is that of Ratna and Saleh in Lajar Terkembang. This marriage, it seems, is intended to provide a model for the style of nationally-dedicated marriage Tuti's and Jusuf's should be. In fact, it only serves to emphasize that for Alisjahbana, the ideal role of a woman is to struggle alongside her husband, doing those things which she, as a woman, can do best. Single-blessedness is impossible, even dangerous to the personality, as Tuti's earlier life shows. The idea of free love, with the woman having complete rights over the disposal of her body, is nowhere remotely possible.

Indonesian literature, then, avoids the problems of dealing with passionate relationships between equals by the sentimental restructuring of the relationship, either honorably into a pseudo-kinship tie, or into liaisons with outcast women. It is difficult to see on what basis any adjustment towards fully equality between lovers is possible in Indonesian literature when passion is not for nice people.

34. Horison, 1, No. 5 (1966), p. 150.

35. See, however, the comments of Idrus, "Angkatan'66 dan TjerpenTjerpen Horison," Horison, 2, No. 7 (1967), pp. 198-199. 